\title{
Preparation of gluten-free crab nugget (Ucidescordatus) with added fiber
}

\section{Elen Vanessa Costa da Silva ${ }^{1^{*}}$ (iD Maria Deyonara Lima da Silva ${ }^{1}$ (D)}

${ }^{1}$ Departamento de Tecnologia de Alimentos, Centro de Ciências Naturais e Tecnologia, Universidade do Estado do Pará (UEPA), Castanhal, PA, Brasil. E-mail: elen.vanessa@bol.com.br. ${ }^{*}$ Corresponding author.

ABSTRACT: Crab meat is rich in nutrients such as polyunsaturated fatty acids, minerals, and vitamins. Its catch is one of the most important fishing modalities in the North Brazilian state of Pará; however,crab is under utilized in the food industry and mainly sold as fresh meat. The study aimed to develop three formulations of gluten-free crab nuggets with added fiber. To reduce the cost of the final product, three formulations $(F 1, F 2$, and F3) were developed by the addition of rice flour at $0 \%$ (F1), 15\% (F2), and 30\% (F3) as a partial replacement of crab meat. Physicochemical and microbiological analyses were performed according to the legislation. In sensory intent analysis, F1 and F2 stood out in relation to F3, butall formulations were well accepted. The cost per unit of the formulations was 0.37 Brazilian reals (R\$) for F1, $R \$ 0.27$ for F2, and $R \$ 0.24$ for F3; the formulations obtained a $90.47 \%$ yield. For fibers, the same result (0.96 g-dry basis) was obtained for all three formulations.

Key words: nuggets, celiac, low cost.

Elaboração de nugget de caranguejo (Ucidescordatus) adicionado de fibras e sem glúten

RESUMO: O caranguejo é rico em nutrientes, como os ácidos graxos poli-insaturados, minerais e vitaminas. A sua captura é uma das modalidades de pesca de maior importância paraense, porém é subutilizado na indústria alimenticia, vendido principalmente na forma in natura. O objetivo deste estudo foi desenvolver três formulações de empanado (nugget) de caranguejo adicionado de fibras e sem glúten. Visando baratear o custo do produto final foram elaboradas as formulações F1, F2 e F3, as quais se distinguiram na adição de farinha de arroz com $0 \%(F 1), 15 \%(F 2)$ e 30\%(F3) em substituição parcial de caranguejo. Obteve-se para as análises físico-químicas e microbiológicas resultados de acordo com a legislação. Na análise sensorial de intenção as F1 e F2 se sobressaíram em relação à F3, e todas as formulações foram bem aceitas. $O$ custo por unidade das formulações foi $R \$ 0,37(F 1), R \$ 0,27(F 2)$ e R\$ 0,24(F3); as formulações obtiveram $90,47 \%$ de rendimento. Para fibras obteve-se o mesmo resultado $(0,96 g-$ b.s.) nas três formulações.

Palavras-chave: nuggets, celíacos, baixo custo.

\section{INTRODUCTION}

Fishing and aquaculture are important sources of employment, especially in developing countries (FAO, 2016). In Brazil, the Northern State of Pará was the largest producer of fish and seafood from aquaculture in 2011, with a total of 142,900 tons, but its aquaculture production is still below its potential. However, territorial extension, water availability, agricultural vocation, logistics favorable to export by sea, and high per capita consumption of fish as well as the state of over exploitation of the main fish stocks make this state a powerful candidate for Brazilian fish farming (BRAZIL, 2013a; IBGE, 2015; BRABO, 2014).

One of the most socially important fishing modalities in the state of Pará is the capture of the uçá crab (Ucidescordatus), which employs a large number of workers (GLASER et al., 2005). The greatest problems in fishing today are related to the devaluation of fishery resources, such as the under utilization of fishery products and the lack of diversification of fish-processing industry. According to BANDEIRA \& NASCIMENTO (2017), fish processing is an alternative to meet the protein needs of the population.

Because fish is a rich source of proteins with high biological value, containing essential amino acids, unsaturated fatty acids, vitamins, and minerals (FAO, 2016) as well as a low cholesterol content, it is a healthier option for consumption than other meats (GONÇALVES, 2011). In addition to being an energy source for the body, the lipids present 
in fish,i.e., omega-3 fatty acid, docosahexaenoic acid, eicosapentaenoic acid, function as a vehicle for fat-soluble vitamins that have regulatory or coenzyme functions, are precursors in the synthesis of prostaglandins and steroid hormones that play important roles in controlling body homeostasis (RAMÍREZ et al., 2001; BADOLATO et al., 1991), and are important for an optimal neurological development in children as well as for cardiovascular health (FAO, 2016).

However, fish consumption is based on locally available product (FAO, 2014a). Fish byproducts are not usually available in the market, either due to low acceptance by consumers or because health regulations restrict their use (FAO,2016). Processed products derived from the $u c ̧ a ́$ crab could be alternative for the industrialization and popularization of fish because crustacean meat is appreciated in various parts of the world for its texture,unique flavor,and high content of proteins and other nutrients, including essential amino acids recommended by the FAO (1973), particularly lysine, that is present in small amountsin cereals, which is frequently consumed by humans. Furthermore, crab meat is a source of polyunsaturated fatty acids and physiologically important minerals, such as magnesium, manganese, zinc, and copper as well as water-soluble vitamins of the B complex and fat-soluble vitamins (A and D) (OGAWA \& MAIA, 1999).

The Brazilian Food Composition Table (TACO) includes values for $100 \mathrm{~g}$ of cooked crab meat. Macronutrients are in the following concentrations: protein, $18.5 \mathrm{~g}$; ash, $3.5 \mathrm{~g}$; total lipids, $0.4 \mathrm{~g}$; saturated fats, $0.2 \mathrm{~g}$; monounsaturated fats, $0.2 \mathrm{~g}$; omega-3 polyunsaturated fatty acids, trace amounts; cholesterol, $85 \mathrm{mg}$; and no carbohydrates. Micronutrients are ] as follows: calcium, $357 \mathrm{mg}$; magnesium, $52 \mathrm{mg}$; manganese, $0.07 \mathrm{mg}$; phosphorus, $154 \mathrm{mg}$; iron, 2.9 mg; sodium, $360 \mathrm{mg}$; potassium, $186 \mathrm{mg}$; copper, 0.72 $\mathrm{mg}$; zinc, $5.7 \mathrm{mg}$; thiamine, $0.04 \mathrm{mg}$; riboflavin, 0.31 $\mathrm{mg}$; niacin, $4.17 \mathrm{mg}$; and trace amounts of vitamin $\mathrm{C}$, retinol, and pyridoxine. Among its physicochemical characteristics, it has $77 \%$ moisture and a caloric value of $83 \mathrm{kcal}$ (TACO, 2011).

The elaboration of breaded nuggets from crab meat can contribute to an increase in the consumption of this protein source because of its practicality at the time of preparation and the sensory variety of nuggets (BONACINA \& QUEIROZ, 2007).

In addition, another component has become an essential part in the formulation of food products, i.e., soluble fibers, because they provide functional benefits and marked positive health effects, such as the prevention or treatment of chronic non-communicable diseases and their manifestations like obesity, hypertension, cancer, blood glucose and cholesterol levels, constipation, cardiovascular diseases, metabolic syndrome, etc. It is a functional ingredient that can be easily incorporated into meat products because of its rheological peculiarities, thus producing enriched foods without impairing the sensory attributes and product acceptability (MENESES \& GIUNTINI, 2013; FRUET et al., 2014; GAVANSKI et al., 2015; MARTINO et al., 2016; SOUSA et al., 2019).

To cover gluten-intolerant consumers, the industry of breaded products seeks to completely replace wheat flour with gluten-free ingredients, of which one of the most suitable is rice flour, because it is a versatile product with hypo allergenic properties, low sodium levels, mild flavor, and easily digestible carbohydrates (SIVARAMAKRISHNAN; SENGE; CHATTOPADHYAY, 2004).

The study arises from a perception of the unavailability of industrialized crab-derived food products, aiming to seek the elaboration of a nutritious, practical, functional, and financially accessible food alternative from the elaboration of gluten-free crab nuggets with added fibers, while also adding value to regional raw materials and providing safe food for gluten-intolerant consumers.

\section{MATERIALS AND METHODS}

For the preparation of the nuggets, frozen crab meat and other ingredients were selected at the municipal market of the town of Castanhal, State of Pará, Brazil. The preparation and analysis were performed in the food laboratory of the State University of Pará (UEPA).

\section{Preparation of formulations}

Three nugget formulations were developed adapting the methods of FRANCISCO BELTR ̃̃O (2012), EVANGELISTA-BARRETO et al. (2016) and SILVA et al. (1998). Rice flour was added as a partial replacement to crab meat: Formulation 1 (F1), without substitution; Formulation 2 (F2), 15\% rice flour; and Formulation 3 (F3), 30\% rice flour. The same fiber percentages were added to all formulations (5\% flaxseed, $9 \%$ sesame, and $13 \%$ textured soy protein).

The fibers were crushed in a household blender until they completely homogenize with the other ingredients of the formulation. The formulation was then molded and stored under refrigeration for 4 hours at $-18{ }^{\circ} \mathrm{C}$ to achieve abetter consistency. After refrigeration, the nuggets were breaded with predust rice flour, followed by a batter of starch and milk, and a final breading with corn flour. The final 
products were pre fried in vegetable oil at $180{ }^{\circ} \mathrm{C}$ for $1 \mathrm{~min}$. After cooling, some of the nuggets were sent for microbiological analysis and the rest were stored in a domestic freezer at a temperature between $-10{ }^{\circ} \mathrm{C}$ and $-8{ }^{\circ} \mathrm{C}$ until the time of microbiological, physicochemical, and sensory analysis, where they were fried in soybean oil at $180{ }^{\circ} \mathrm{C}$ for $5 \mathrm{~min}$.

\section{Physicochemical analyses}

Analysis of the centesimal contents of ash, lipids, proteins, moisture, and carbohydrates were performed in triplicates,in accordance with the norms of the Adolfo Lutz Institute (2008). The total caloric value, expressed in kcal, was calculated using the At water coefficients (carbohydrates, 4 kcal.g-1; proteins, 4 kcal.g-1; and lipids, 9 kcal.g-1; BONACINA \& QUEIROZ, 2007).

\section{Microbiological analysis}

Microbiological analyses were performed for coagulase-positive Staphylococcus according to IS0 6888-1:1999, coliform bacteria at $45^{\circ} \mathrm{C}$ according to IN-62 MAPA, and Salmonella sp. according to ISO 6579:2002. The results were compared with Collegiate Resolution 12 of January 2, 2001 of the Brazilian National Sanitary Surveillance Agency (ANVISA) that specifies microbiological parameters for "packaged and frozen foods" (BRAZIL, 2001).

\section{Sensory analysis}

Tests were performed at the UEPA food laboratory in individual cabins. Nugget consumers were selected among university staff and students. Consumers received an evaluation sheet for each sample. In the acceptance test, the nuggets were evaluated for appearance, aroma, flavor, texture, and overall impression using a hedonic scale of nine points, in which score 1 corresponded to "totally disliked" and score 9 to"liked very much." The samples were randomly coded with three-digit numbers. In addition, we used the intent test with a five-point scale,in which score 1 corresponded to "would never buy it" and score 5 to "definitely would buy it," aiming to evaluate the purchase intention if these nuggets were available in the food market. The samples were separately served in a randomized manner. Thereafter, the preference test was performed, in which the evaluator indicated in descending order his preference, and the samples were simultaneously and randomly served. A total of 73 untrained judges participated in the tests.

\section{Cost and yield analysis}

The yield calculations were performed according to ROSALES, BARRIGA \& CASTRO
(2004) through the relationship between the final product and the initial quantity of raw material using Equation 1. Furthermore, the cost was calculated (Equation 2) based on the price and quantity of raw material used for the preparation of the product (SANTOS, 1999).

Equation 1:

Yield $(\%)=($ weight of prefried product/weight of breaded product) $\times 100$

Equation 2:

Cost $(\mathrm{R} \$)=$ quantity $\times$ price of raw material.

\section{Statistical analysis}

The results were analyzed using analysis of variance (ANOVA) at 5\% significance level $(\mathrm{p}<0.05)$, and a subsequent Tukey's test was performed in Microsoft ${ }^{\circledR}$ Office Excel software. The results are presented as means and standard deviations for the three nugget formulations.

\section{RESULTS AND DISCUSSION}

\section{Physicochemical analysis}

The result of the centesimal humidity (Table 1) for F1 (41.8\%) did not significantly differ $(\mathrm{p}<0.05)$ from $\mathrm{F} 2 \quad(39.2 \%)$, but differed from $\mathrm{F} 3$ (36.5\%). LEITE et al. (2018) reported a moisture content of $7.78 \%$ for rice flour, which was much lower than TACO's (2001) for cooked crab, which was $77 \%$. This justifies the direct relationship between the percentage of moisture and partial replacement content of crab with rice flour, in which higher the substitution, lower is the moisture content because of the low humidity present in rice flour; consequently,changing the moisture level of the final product. The moisture content of crab nuggets was lower than the results described by NOLETO et al., (2017) in their study of nuggets with pulp of the shrimp Litopenaeus vannamei and their nutritional content, in which a high percentage of humidity $(66.94 \%)$ was reported.

F1 with $14.7 \%$ lipids did not significantly differ from F2 (12.1\%), but differed from F3 (9.9\%). The addition of vegetable oil and pre frying, according to FUKUSHIMA et al. (2014), contributes to a $4 \%$ increase in fat and a consequent increase in the lipid content of breaded products when compared with the raw breaded product because of oil absorption during the pre-frying process. The difference in lipid content is related to the concentration of crab meat, constituting an important energy source, in addition to polyunsaturated omega-3 fatty acids, which hasa reducing effect on triglyceride and blood cholesterol rates (OGAWA \& MAIA, 1999).

The percentages of ash for F1 (3.9\%), F2 (3.6\%), and F3 (3.2\%) did not significant difference, 
Table 1 - Results of the centesimal composition of nuggets based on wet weight.

\begin{tabular}{|c|c|c|c|c|}
\hline Parameters g/100g & 1 & 2 & 3 & Brazil,2012 \\
\hline Humidity (\%) & $(41.8 \pm 0.7)^{a}$ & $(39.2 \pm 0.8)^{a b}$ & $(36.5 \pm 0.1)^{b}$ & - \\
\hline Lipids (\%) & $(14.7 \pm 0.4)^{a}$ & $(12.1 \pm 0.2)^{a b}$ & $(9.9 \pm 0.1)^{b}$ & - \\
\hline Ash (\%) & $(3.9 \pm 1.0)^{a}$ & $(3.6 \pm 0.2)^{a}$ & $(3.2 \pm 0.1)^{a}$ & \\
\hline Protein (\%) & $(30.5 \pm 1.9)^{a}$ & $(29.1 \pm 1.9)^{a}$ & $(28.6 \pm 0.3)^{a}$ & $\geq 10$ \\
\hline Carbohydrates(\%) & $(10.3 \pm 2.5)^{a}$ & $(16.1 \pm 1.7)^{b c}$ & $(20.4 \pm 0.3)^{c}$ & $\leq 30$ \\
\hline Fibers $^{*}(\%)$ & 0.96-dry basis & 0.96-dry basis & 0.96-dry basis & $3 \mathrm{~g} / 100 \mathrm{~g}$ \\
\hline $\mathrm{CV}^{* *}(\mathrm{kcal} / 100 \mathrm{~g})$ & $(296.9 \pm 3.1)^{a}$ & $(286.7 \pm 4.4)^{b c}$ & $(287 \pm 0.3)^{c}$ & - \\
\hline
\end{tabular}

(-) item is not listed in Brazilian legislation. Within the same line, followed by equal letters do not differ statistically from each other at the 5\% significance level in Tukey'stest.

${ }^{*}$ Fiber results are based on dry weight; ${ }^{* *} \mathrm{CV}($ caloric value).

indicating the presence of inorganic matter such as minerals. Crab meat is a source of physiologically important minerals such as zinc, magnesium, manganese, zinc, and copper (OGAWA \& MAIA, 1999; PEDROSA \& COZOLINO, 2001). The values for ash reported in the nuggets were similar to those reported by EVANGELISTA-BARRETO et al., (2016) who madegluten-free nuggets from Serra Spanish mackerel meat (Scomberomorus brasiliensis) flavored with basil and rosemary and obtained percentages of $3.19 \%$ and $3.10 \%$, respectively.

For protein, F1 (30.5\%), F2 (29.1\%), and F3 (28.6\%) did not significantly differ from each other. These values were much higher than those observed by NOLETO et al. (2017) in shrimp nuggets, where a protein content of $15.39 \%$ was reported, and by VEIT et al., (2001) who reported $14.67 \%$ protein nuggets made from mandi-pintado (Pimelodus britskii) fish meat. EVANGELISTA-BARRETO et al. (2016) reported $22.33 \%$ and $19.80 \%$ of protein in gluten-free fish nuggets with added basil and rosemary, respectively. Results of crab nuggets were high due to the addition of fiber, such as soybean,which reduces total humidity according to MOREIRA et al. (2016),thus increasing the protein content up to $45 \%$. Additionally, crab meat has a high content of protein (FAO, 1973).

For carbohydrates, F1 (10.3\%) significantly differed from F2 (16.1\%), which in turn did not significantly differ from F3 (20.4\%). Results were proportional to the substitution of rice flour for crab because rice flour has high carbohydrate content (SILVA et al., 2007),; whereas, crab meat has insignificant values (TACO, 2011).

For fiber, the same result ( $0.96 \mathrm{~g}$ dry basis) was obtained for all three formulations because the same type of fiber was added in equal concentrations. They did not qualify as fiber-rich foods because they had a lower content than the minimum requirement recommended by the Brazilian legislation ( $3 \mathrm{~g}$ per $100 \mathrm{~g}$ of product) (BRAZIL, 2012). The American Dietetic Association (2002) recommends the intake of 20-35 g of fiber/day for healthy adults; thus, the intake of a portion of the prepared product corresponds to up to $4.8 \%$ of the daily amount of fiber recommended for a healthy adult. BERNAUD \& RODRIGUES, (2013) reinforced the need for fiber consumption because it is associated with a significant reduction in glucose, blood pressure, and serum lipid levels.

For caloric value, F1 (296.9 kcal) significantly differed from F2 $(286.7 \mathrm{kcal})$, which in turn did not significantly differ from F3 (287 $\mathrm{kcal})$. The values were higher than those found by EVANGELISTA-BARRETO et al. (2016) who reported 216.15 and $205.97 \mathrm{kcal}$ for gluten-free nuggets made from Serra Spanish mackerel meat (Scomberomorus brasiliensis) flavored with basil and rosemary, respectively, probably due to the significant protein content and its influence on energy calculation.

\section{Sensory analysis}

Sensory analysis was performed after the study was approved by the Ethics Committee of the Center for Biological and Health Sciences of the State University of Pará (Approval number 2.629.039). In the acceptance test, F1 obtained the highest scores, followed by F2 and F3 varying between scores 7 and 6 corresponding to "liked moderately" and "liked slightly," respectively. From ANOVA for sensory acceptance, there was a significant difference at 5\% probability level. As per Tukey's test (Table 2), F1

Ciência Rural, v.49, n.12, 2019. 
Table 2 - Sensory evaluation of gluten-free crab nuggets with added fibers.

\begin{tabular}{lccccc}
\hline Formulations & Overall Impression & Texture & Flavor & Color \\
\hline 1 & $(7.6 \pm 1.05)^{a}$ & $(7.4 \pm 1.22)^{a}$ & $(7.4 \pm 1.69)^{a}$ & $(7.3 \pm 1.10)^{a}$ & $(7.4 \pm 1.33)^{a}$ \\
2 & $(7.3 \pm 1.24)^{a}$ & $(7.1 \pm 1.47)^{a}$ & $(7 \pm 1.36)^{a}$ & $(6.6 \pm 1.43)^{b}$ & $(7.2 \pm 1.22)^{a}$ \\
3 & $(6.4 \pm 1.61)^{b}$ & $(6.6 \pm 1.83)^{b}$ & $(5.6 \pm 2.18)^{b}$ & $(6.3 \pm 1.59)^{b}$ & $(6.7 \pm 1.67)^{b}$ \\
\hline
\end{tabular}

${ }^{*}$ Within the same column, followed by equal letters do not statistically differ from each other at the $5 \%$ significance level. Hedonic scale (between parentheses) followed by the Tukey's test result for overall impression, texture, flavor, color and aroma.

and F2 significantly differed from each other for the color attribute, where as for the other attributes they showed no statistically significant differences. However, both differed from F3. The F3 formulation only equaled F2 in the color attribute, differing in all attributes in relation to F1 (Figure 1).

For F1 and F2,the partial replacement of crab mass with rice flour at $15 \%$ was not noticeable by the consumer in terms of flavor, aroma, and texture. There fore, this substitution can be done to decrease costs while offering the desired sensory characteristics for the nugget. However, the color attribute showed a significant difference as a result of the addition of rice flour because this gave the product a darker appearance compared with the golden color of the formulation without the addition of rice flour $(\mathrm{F} 1)$.

In the purchase intent test, only F1 and F2 obtained acceptability indices above $70 \%$ with $81.8 \%$ and $77.8 \%$ rates, respectively. F3 with $58 \%$ acceptance indicated a weak market potential. The analysis of the preference test and subsequent Friedman test revealed that $\mathrm{F} 1$ and $\mathrm{F} 2$ did not significantly differ $(\mathrm{P}<0.05)$ in preference, with F3 being the least preferred.

\section{Microbiological analysis}

Microbiological parameters were within the limits established by ANVISA in Collegiate Resolution 12 (Table 3), indicating that the nuggets were processed under appropriate conditions; and therefore,were

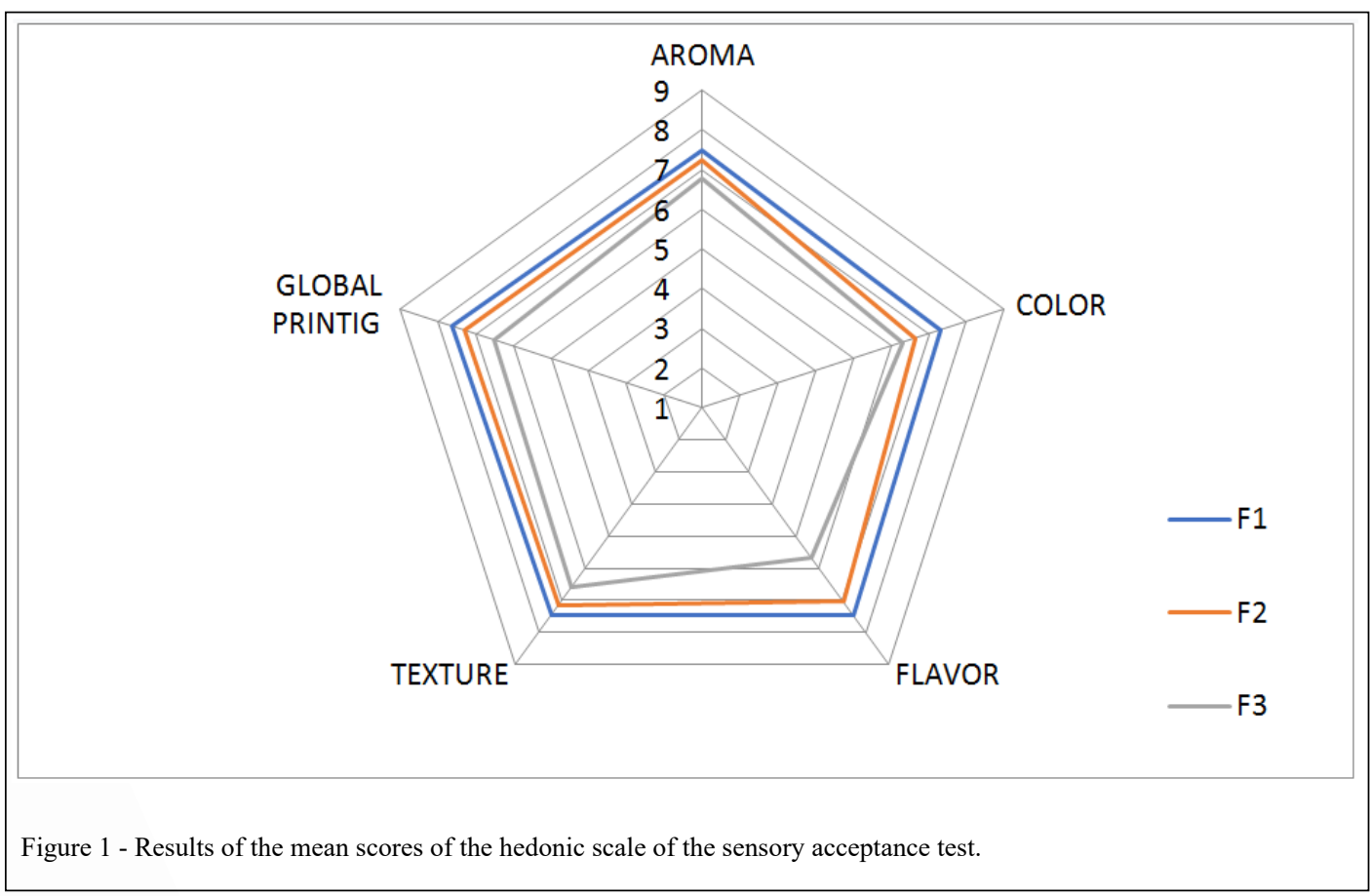

Ciência Rural, v.49, n.12, 2019. 
Table 3 - Microbiological analysis of nuggets.

\begin{tabular}{|c|c|c|c|c|}
\hline Parameters & Formulation 1 & Formulation 2 & Formulation 3 & Legislation \\
\hline Salmonella (25 g) & Absent & Absent & Absent & Absent \\
\hline $\begin{array}{l}\text { Coagulase-positive } \\
\text { Staphylococcus/gCFU/g }\end{array}$ & Absent & Absent & Absent & $10^{3}$ \\
\hline $\begin{array}{l}\text { Coliform bacteria at } 45^{\circ} \mathrm{C} \\
\mathrm{MPN} / \mathrm{g}\end{array}$ & $<3$ & $<3$ & $<3$ & $10^{3}$ \\
\hline
\end{tabular}

*ANVISA (2001) — Collegiate Resolution 12.

suitable for consumption. The values reported for coliform bacteria were below the limits established by Brazilian legislation, and Salmonella and coagulasepositive Staphylococcus were absent, indicating that sanitary hygienic procedures were correctly followed at all stages of processing. According to VEIT et al., (2011), the adoption of sanitary hygienic procedures in handling, processing, and other activities in food production are important measures to reduce contamination levels and prevent introduction of pathogens.

Similar results were reported by SILVA et al. (1998), who reported an absence of coagulasepositive Staphylococcus and Salmonella sp. in microbiological analyses of fish-residue nuggets. Moreover, NOLETO et al. (2017) obtained the same microbiological results for shrimp nuggets. The combination of pre-frying time and temperature used before microbiological analysis may have contributed to microbiological quality. According to SILVA et al. (1998), nuggets have several stages of processing; therefore, controlling food temperature is of paramount importance to avoid possible microbiological contamination, as recommended by good manufacturing practices.

\section{Cost and yield analysis}

There is a direct relationship between decrease in the cost of production and replacement of crab meat with rice flour; this is because of the affordable price of rice flour compared with that of crab meat. One nugget unit was found to weigh approximately $9.5 \mathrm{~g}$, with a yield of $90.47 \%$ for all formulations, which resulted in a total cost per unit of 0.37 Brazilian reals ( $\mathrm{R} \$$ ) for $\mathrm{F} 1, \mathrm{R} \$ 0.27$ for $\mathrm{F} 2$, and R\$0.24 for F3 (Table 4). The elaboration of the nuggets resulted in a high-protein crab derivative with a low production cost that can be marketed at an affordable price.

\section{CONCLUSION}

All three formulations achieved microbiological quality standards, high protein levels, and compliance with Brazilian legislation in physicochemical parameters. The formulation with $15 \%$ added rice flour (F2) stood out for the lower production cost and was the most suitable for production and marketing due to nutritional, sensory, and financial reasons.

Table 4 - Yield and cost of formulations.

\begin{tabular}{lccc}
\hline & Formulation 1 & Formulation 2 & Formulation 3 \\
\hline Final weight of preparation ( $\mathrm{g})$ & 188 & 188 & 188 \\
Average yield (number of servings) & 24 & 24 & 24 \\
Total cost of the preparation (R\$) & 9.05 & 6.51 & 5.81 \\
Cost per portion (R\$) & 0.37 & 0.27 & 0.24 \\
\hline
\end{tabular}

Ciência Rural, v.49, n.12, 2019. 


\section{ACKNOWLEDGEMENTS}

The authors thank the Fundação Amazônia de Amparo a Estudos e Pesquisas (FAPESPA) for financial support for this work.

\section{BIOETHICS AND BIOSSECURITY COMMITTEE APPROVAL}

The study was approved by the Ethics Committee of the Center for Biological Sciences and Health of the State University of Pará (Approval number 2.629.039).

\section{DECLARATION OF CONFLICT OF INTERESTS}

The authors declare no conflict of interest. The founding sponsors had no role in the design of the study; in the collection, analyses, or interpretation of data; in the writing of the manuscript, and in the decision to publish the results.

\section{AUTHORS' CONTRIBUTIONS}

The authors contributed equally to the manuscript.

\section{REFERENCES}

ADOLFO LUTZ INSTITUTE. Métodos Físico-químicos para análises de alimentos. [Physico-chemical methods for foodanalysis]. 4th ed. 1stdigital ed. São Paulo: Adolfo Lutz Institute, 2008. Available from: <http://www.ial.sp.gov.br/resources/ editorinplace/ial/2016 3 19/analisedealimentosial 2008.pdf $>$. Accessed: May, 10, $201 \overline{8}$

AMERICAN DIETETIC ASSOCIATION. Position of the American Dietetic Association: health implications of dietary fiber. J. Am. Diet. Assoc., v.102, p.993-1000, 2002. Available from: $<$ https://www.ncbi.nlm.nih.gov/pubmed/18953766>. Accessed: Jan. 10, 2018. doi: 10.1016/j.jada.2008.08.007.

BADOLATO, ESG et al. Determination of eicosapentaenoic and docohexasapentenoic acids in Brazilian sardine oil (Sardinella brasiliensis) and in dietary supplements based on sardine oil. Rev Inst Adolfo Lutz; v.3, p.21-3, 1991. Available from: <https://www semanticscholar.org/paper/Determination-of-eicosapentaenoic(EPA)-and-(DHA)-Badolato-Carvalho/4fa61814e1bdd6928d9dbf7 24a644a686a813109>. Accessed: May, 10, 2018.

BRABO, M. F. Piscicultura no Estado do Pará: situação atual e perspectivas. [Aquaculture in the State of Pará: current situation and prospects]. Acta Fish. Aquat. Res. v.2, n.1, p.17, 2014. Available from: <https://seer.ufs.br/index.php/ActaFish/ article/view/3021>. Accessed: May, 01, 2018. doi: 10.2312/ Actafish.2014.2.1.i-vii.

BANDEIRA, M. G. A.; NASCIMENTO, J. S. Estudo prospectivo relativo à atividade da tilápia para a indústria de alimentos no período de 2006 a 2016. [Prospective study on tilapia activity for the food industry from 2006 to 2016.] Cad. Prospec., Salvador, v.10, n.3 p.552-562, Jul./Sep. 2017. Available from: <https:// portalseer.ufba.br/index.php/nit/article/view/23029>. Accessed: Jan. 21, 2018. doi: 10.9771/cp.v10i3.23029.
BRAZIL, Ministry of Fisheries and Aquaculture. Boletim Estatístico de Pesca e Aquicultura do Brasil 2011. [Statistical Bulletin of Fisheries and Aquaculture in Brazil, 2011]. Brasília: Federative Republic of Brazil, 2013a. Available from: <http:// bibspi.planejamento.gov.br/handle/iditem/191>. Accessed: Jan. 28,2018

BRAZIL. Normative Instruction 6, of 15 February 2001 Regulamentos técnicos de identidade e qualidade de paletacozida, produtos cárneos salgados, empanados, presunto tipo serrano e prato elaborado pronto ou semi-pronto contendo produtos de origem animal. [Technical regulations for the identity and quality of cooked shoulder-clod beef, salted meat products, breaded products, Serrano-type ham, and cooked or semi cooked prepared dishes containing products of animal origin]. Diário Oficial da União, Brasília, Section1, p.60, 19 February 2001. Available from: <http://sidago.agrodefesa.go.gov.br/site/adicionaisproprios/ protocolo/arquivos/408764.pdf $>$. Accessed: Feb. 09, 2018.

BRAZIL. Normative Instruction 62 of 26 August 2003. Métodos analíticos oficiais para análises microbiológicas para controle de produtos de origem animal e água. [Official analytical methods for microbiological analysis for the control of products of animal origin and water]. Ministry of Agriculture, Livestock and Supply (MAPA). Diário Oficial da União, Brasília, Section 1, p.14, 18, September 2003. Available from: <https://www.defesa. agricultura.sp.gov.br/legislacoes/instrucao-normativa-sda-62de-26-08-2003,665.html>. Accessed: Feb. 03, 2018.

BRAZIL, National Sanitary Surveillance Agency. Collegiate Resolution 54. Regulamento Técnico sobre Informação Nutricional Complementar. [Technical Regulationon Supplementary Nutritional Information]. Diário Oficial da União, Brasília, 12 November 2012. Available from: <http://portal.anvisa.gov.br/documents/\%20 33880/2568070/rdc0054 12 11 2012.pdf/c5ac23fd-974e-4f2c9fbc-48f7e0a31864>. Accessed: Feb. 01, 2018.

BERNAUD, F. S. R. \& RODRIGUES, T. C. Fibra alimentar - Ingestão adequada e efeitos sobre a saúde do metabolismo. [Dietary fiber - Adequate intake and effects on the health of metabolism]. Arq Bras Endocrinol Metab. 2013;57/6. Available from: $\quad<$ http://www.scielo.br/scielo.php?script=sci arttext\&pid $=$ S0004-27302013000600001 $>$. Accessed: Nov. 20, 2017. doi: 10.1590/S0004-27302013000600001.

BONACINA M. S. \& QUEIROZ, M. I. Elaboração de empanado a partir da corvina (Micropogonias furnieri).Preparation of breaded nuggets from croaker meat (Micropogonias furnieri)]. Ciênc. Tecnol. Aliment., v.27, n.3, p.544-52, 2007. Available from: <http://www. scielo.br/scielo.php?pid=S0101-20612007000300019\&script=sci abstract\&tlng=pt>. Accessed: Jan. 11, 2018 doi: 10.1590/S010120612007000300019

EVANGELISTA-BARRETO, S. et. al. Elaboração de nuggets de sororoca (Scomberomorus brasiliensis) sem glúten e saborizados com manjericão e alecrim. [Preparation of gluten-free nuggets from Serra Spanish mackerel meat (Scomberomorus brasiliensis) flavored with basil and rosemary]. Rev. Bras. Eng. Pesca, v.9, n.2, p.107-119, 2016. ISSNe 2175-3008. Available from: <http://45.71.6.41/index.php/REPESCA/article/view/1145>. Accessed: Jan. 29, 2018. doi: 10.18817/repesca.v9i2.1145.

FRUET, A. P. B. et al. Incorporação de fibra alimentar em produtos cárneos. [Incorporation of dietary fiberinto meat products]. Rev. Centro do Ciências Naturais e Exatas - UFSM, Santa Maria, v.18, p.11-17, Special Ed., May 2014. Available from: <https://

Ciência Rural, v.49, n.12, 2019. 
www.researchgate.net/publication/276244860>. Accessed: Feb. 22, 2018. doi: $10.5902 / 2236117013030$

FUKUSHIMA, K. L. et al. Características químicas, microbiológicas e sensoriais de empanados formulados à base de carne mecanicamente separada de tilápia-do-nilo (Oreochromisniloticus).[ Chemical, microbiological and sensory characteristics of breaded nuggets elaborated from mechanically separated Nile-tilapiameat (Oreochromisniloticus).. Hig. Alim., v.28, n.238-239, p.181-186, 2014. Available from: <https:// www.researchgate.net/publication/284040728>. Accessed: Mar. 05, 2018.

FOOD AND AGRICULTURE ORGANIZATION OF THE UNITED NATIONS. FAO. Energy and Protein Requirements: Report of a joint FAO/WHO Ad Hoc Expert Committee/FAO. Rome, 1973, 118p. Available from: <https://apps.who.int/iris/ handle/10665/41042>. Accessed: Nov. 01, 2017.

GAVANSKI, D. S.; BARATTO, I.; GATTI, R. R. Avaliação do hábito intestinal e ingestão de fibras alimentares em uma população de idosos. [An evaluation of intestinal frequency and dietary fiber ingestion in a population of elderly people]. Rev. Brasileira de Obesidade, Nutrição e Emagrecimento, São Paulo. v.9. n.49. p.3-11. Jan./Feb. 2015. ISSN 1981-9919. Available from: <http:// www.rbone.com.br/index.php/rbone/article/view/341>. Accessed: Oct. 01, 2017.

GLASER, M.; CABRAL, N.; RIBEIRO, A. (Orgs.). Gente, ambiente e pesquisa: manejo transdisciplinar no manguezal. [People, environment, and research: transdisciplinary management of the mangrove]. Belém: NUMA/UFPA, 2005.

GONÇALVES, A. A. Tecnologia do pescado: ciência, tecnologia, inovação e legislação. [Fishtechnology: science, technology, innovation,andlegislation]. São Paulo: Ed. Atheneu, ISBN 97885-388-0197-9, 2011

IBGE (BRAZILIAN INSTITUTE OF GEOGRAPHY AND STATISTICS). State of Pará, 2015. Available from: <https:// cidades.ibge.gov.br/?sigla=pa>. Accessed: Mar. 20, 2019.

\section{INTERNATIONAL}

ORGANIZATION

FOR

STANDARDIZATION. ISO 6579:2002. Microbiology of Food and Animal Feeding Stuffs - Horizontal Method for the Detection of Salmonella spp. Geneva: ISO, 2002.

GLASER, M. Interrelações entre o ecossistema manguezal, a economia local e a sustentabilidade social no estuário do Caeté, Norte do Brasil. [Interrelations between the mangrove ecosystem, the local economy, and social sustainability in the Caeté estuary, Northern Brazil]. In: GLASER, M.; CABRAL, N.; \& RIBEIRO, A.L (Org.) Belém: NUMA/UFPA, p.37-49. 2005.

LEITE, N. D. et al. [Rice and eggplant flours in pasta: chemical and physical properties]. Segur. Aliment. Nutr., Campinas, v.25, n.1, p.65-75, Jan./Abr. 2018. Available from: <https://periodicos.sbu. unicamp.br/ojs/index.php/san/article/view/8650927>. Accessed: Jan. 10, 2018. doi: 10.20396/san.v25i1.8650927.

MARTINO, H. S. D. et al. Fibra alimentar. [Food fiber.] In: COSTA, N. M. B.; \& ROSA, C. O. B. Alimentos funcionais compostos bioativos e efeitos fisiológicos. [Functional foods bioactive compounds and physiological effects]. 2. ed. Rio de Janeiro: Rubio, 2016. chap.4, p.49-60.
MENESES, E. W. \& GIUNTINI, E. B. Fibra alimentar. [Food fiber.] In: COZZOLINO, S. M. F.; \& COMIETTI, C. Bases bioquímicas e fisiológicas da nutrição nas diferentes fases da vida, na saúde e na doença.[Biochemical and physiological bases of nutrition in the different stages of life, in health and in disease]. Barueri, Brazil: Manole, 2013. chap.5, p.136-150.

MOREIRA, M. E. C.; BASTIANE, M. I. D.; MARTINO, H. C. D. Soja: Aspectos nutricionais funcionais. [Soybean: Functional nutritional aspects.] In: COSTA, N. M. B.; \& ROSA, C. O. B. Alimentos funcionais - compostos bioativos e efeitos fisiológicos. [Functional foods - bioactive compounds and physiological effects]. 2. ed. Rio de Janeiro: Rubio, 2016. chap.13, p.189-198.

NOLETO, K. S.; et. al. Elaboração de nuggets com a polpa do camarão Litopenaeus vannamei e seus compostos nutricionais. [Preparation of nuggets with the pulp of the shrimp Litopenaeus vannamei and their nutritional compounds]. Rev. Bras. Eng. Pesca., v.10, n.2, p.85-93, 2017. Available from: <http://ppg. revistas.uema.br/index.php/REPESCA/article/view/1424>. Accessed: Jan. 16, 2018. doi: 10.18817/repesca.v10i2.1424.

OGAWA, M; MAIA, E.L. Química do pescado. [Fish chemistry.] In: OGAWA, M., MAIA, E. L. (Eds.) Manual de Pesca. [Fishing Manual]. São Paulo: Varela, 1999, p.29-70.

PEDrosA, L. F. C.; COZZOLINO, S. M. F. Composição centesimal e de minerais de mariscos crus e cozidos da cidade de Natal/RN. [Centesimal and mineral composition of raw and cooked Shell fish from the city of Natal, State of Rio Grande do Norte]. Cienc. Tecnol. Aliment. v.21, n.2, p.154-157, MayAug. 2001. Available from: <http://www.scielo.br/scielo. php?script $=$ sci_abstract\&pid=S0101-20612001000200006\&lng $=$ pt\&nrm=iso\&t $\operatorname{lng}=\mathrm{en}>$. Accessed: Jan. 16, 2018. doi: 10.1590/ S0101-20612001000200006.

RAMÍREZ, M.; AMATE, L.; GIL, A.; Absorption and distribution of dietary fatty acids from different sources. Early Hum. Dev., v.65, p.95-101, 2001. Avaliable from: <https://www.journals. elsevier.com>. Accessed: Jan. 30, 2018. doi: 10.1016/s0378-3782 (01) 00211-0.

ROSALES, M.; BARRIGA, M.; \& CASTRO, R. Efecto del tiempo de almacenamiento en congelación de pulpa y pasta de pescado y su influencia en la calidad de productos empanizados. [Effect of frozen storage time of fish pulp and paste and its influence on the quality of breaded products]. Bol. Invest. Inst. Tecnol. Pesq. Peru, v.6, p.65-74, 2004. Avaliable from: <http://repositorio.itp. gob.pe/handle/ITP/90>. Accessed: Jan. 27, 2018.

SIVARAMAKRISHNAN, H. P.; SENGE, B.; CHATTOPADHYAY, P. K. Rheological properties of rice dough for making rice bread. J. Food Eng., Kidlington, v.62, n.1, p.37-45, 2004. Available from: <https://www.sciencedirect.com/ science/article/pii/S0260877403001699>. Accessed: Apr. 04, 2018. doi: 10.1016/S0260-8774(03)00169-9.

SILVA, M. R.; SILVA, M. A. A. P; CHANG, Y. K. Use of jatobá (Hymenaea stigonocarpa Mart.) flour in the production of cookies and acceptance evaluation using univariate and multivariate sensory tests. Ciência e Tecnologia de Alimentos, Campinas, Brazil, v.18, n.1, p.25-34, 1998. Available from: $<$ http://www.scielo.br/scielo.php?script=sci_arttext\&pid $=$ S0101-20611998000100007 $>$. Accessed: Nov. 07, 2018. doi: 10.1590/S0101-20611998000100007. 
SILVA, R. F.; ASCHERI, J. L. R.; PEREIRA, R. G. F. A. Composição centesimal e perfil de aminoácidos de arroz e pó de café. [Centesimal composition and amino acid profile of rice and coffee powder]. Alim. Nutr. ISSN 0103-4235, Araraquara, Brazil, v.18, n.3, p.325-330, Jul./Sep. 2007. Available from: $<$ http://serv-bib.fcfar.unesp.br/seer/index.php/alimentos/ article/viewArticle/17>. Accessed: Oct. 06, 2018.

SOUSA, V. B. B. et. al. Constipação intestinal em crianças e a importância das fibras alimentares: Uma revisão da literatura. [Intestinal constipation in children and the importance of dietary fiber: A review of the literature. Rev. Eletrôn. Acervo Saúde. Vol. Sup. 21 and 561, 2019. Available from: $<\mathrm{https}$ ://acervomais.com. br/index.php/saude/article/view/561>. Accessed: Mar. 01, 2019>. doi: 10.25248/reas.e561.2019.
STATE UNIVERSITY OF CAMPINAS. Center for Food Studies and Research. Tabela Brasileira de Composição de Alimentos. [Brazilian Table of Food Composition]. 4th revised and expanded edition. Campinas, Brazil, 2011. 161p. Available from: <http:// www.nepa.unicamp.br/taco/index.php>. Accessed: Feb 13, 2018.

VEIT, J. C.; et. al. Caracterização centesimal e microbiológica de nuggets de mandi-pintado (Pimelodus britskii). [Centesimal and microbiological characterization of nuggets made from mandi-pintado (Pimelodus britskii) fish meat. Semina: Ciências Agrárias, Brazil, v.32,n.3,p.1041-1048, Jul/Sep. 2011. Available from: <https://www.researchgate.net/publication/276228393_ Caracterizacao_centesimal_e_microbiologica_de_nuggets_de mandi-pintado_Pimelodus_britskii $>$. Accessed: Jan. 10, 2018. doi: $10.5433 / 1679-0359.2011 \mathrm{v} 32 \mathrm{n} 3 \mathrm{p} 1041$. 